\title{
GA-A15585
}

UC-77

\section{THE EFFECTS OF THE HTGR-GAS TURBINE ON NATIONAL REACTOR STRATEGIES}

\author{
by \\ D. M. LIGON and R. H. BROGLI
}

Prepared under

Contract DE-AT03-76ET35300 for the San Francisco Operations Office Department of Energy

DATE PUBLISHED: NOVEMBER 1979 


\section{DISCLAIMER}

This report was prepared as an account of work sponsored by an agency of the United States Government. Neither the United States Government nor any agency Thereof, nor any of their employees, makes any warranty, express or implied, or assumes any legal liability or responsibility for the accuracy, completeness, or usefulness of any information, apparatus, product, or process disclosed, or represents that its use would not infringe privately owned rights. Reference herein to any specific commercial product, process, or service by trade name, trademark, manufacturer, or otherwise does not necessarily constitute or imply its endorsement, recommendation, or favoring by the United States Government or any agency thereof. The views and opinions of authors expressed herein do not necessarily state or reflect those of the United States Government or any agency thereof. 


\section{DISCLAIMER}

Portions of this document may be illegible in electronic image products. Images are produced from the best available original document. 
This report was prepared as an account of work sponsored by the United States Government. Neither the United States nor the Department of Energy, nor any of their employees, nor any of their contractors, subcontractors, or their employees, makes any warranty, express or implied, or assumes any legal liability or responsibility for the accuracy, completeness or usefulness of any information, apparatus, product or process disclosed, or represents that its use would not infringe privately owned rights.

Printed in the United States of America

Available from

National Technical Information Service

U.S. Department of Commerce

5285 Port Royal Road

Springfield, Virginia 22161

Price: Printed Copy $\$ 4.00$; Microfiche $\$ 3.00$ 
GA-A15585

UC-77

\title{
THE EFFECTS OF THE HTGR-GAS TURBINE ON NATIONAL REACTOR STRATEGIES
}

\author{
by \\ D. M. LIGON and R. H. BROGLI
}

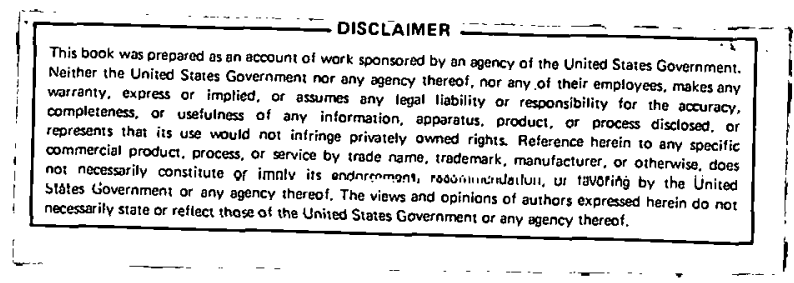

Prepared under

Contract DE-AT03-76ET35300 for the San Francisco Operations Office

Department of Energy

\author{
GENERAL ATOMIC PROJECT 6400 \\ DATE PUBLISHED: NOVEMBER 1979
}

\section{GENERAL ATOMIC COMPANY}




\section{ABSTRACT}

A specific role for the HTGR in a national energy strategy is examined. The issue is addressed in two ways. First, the role of the HTGR-GT Binary cycle plant is examined in a national energy strategy based on symbiosis between fast breeder and advanced converter reactors utilizing the thorium-U233 fuel cycle. Second, the advantages of the HTGR-GT dry-cooled plant operating in arid regions is examined and compared with a dry-cooled LWR. An event tree analysis of potential benefits is applied. 
TABLE OF CONTENTS

$1.0 \quad$ INTRODUCTION. $\ldots \ldots \ldots \ldots \ldots \ldots \ldots \ldots \ldots \ldots \ldots \ldots \ldots \ldots \ldots$

2.0 BASE STRATEGY: FBR/ACR SYMBIOSIS.............. 3

3.0 EFFECTS OF THE HTGR-GT ON THE BASE STRATEGY......... 6

4.0 STRATEGY FOR ARID REGIONS...................... 9

4.1 Event Tree Analysis..................... 12

$5.0 \quad$ CONCLUSION.................................. 19

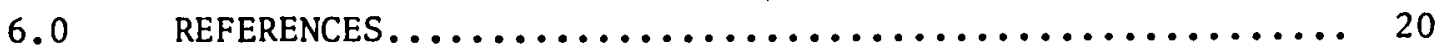


1. Long Term Reactor System.................... 5

2. Potential Benefit of the HTGR-GT in a Symbiotic Energy System............................ 8

3. Total Cost Outlay as a Function of Capital Cost....... 11

4. Sample Assumptions for Evaluating Benefits of the

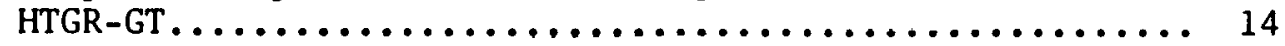

5. Probability Distribution of Benefit from HTGR-GT (Dry-

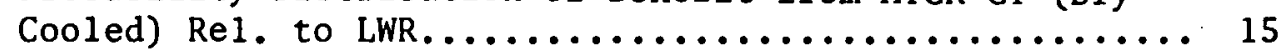

6. Decision Tree for Factors Affecting HTGR-GT Power Cost Relative to Dry-Cooled LWR................. 17

7. Cost Uncertainty of a Dry-Cooled HTGR.............. 18

\section{TABLES}

1. Assumptions.............................. 10

2. Power Cost Components........................ 13

APPENDIX Reactor Mass Flow and Cost Data............... A-1 


\subsection{INTRODUCTION}

In a review of the HTGR program in late 1978, a recommendation was made by DOE to promptly proceed toward the development and commercialization of the gas turbine cycle technology.

The ability of the HTGR to produce energy at high temperatures makes a direct gas turbine cycle possible. This has advantages of increased efficiency, a potential for lower capital cost, increased flexibility and the ability to incorporate dry cooling. Heat rejection options vary in percentage of wet/dry cooling towers. If wet cooling is available, the gas turbine can be combined with a bottoming cycle or low temperature secondary power cycle that generates additional power for increased efficiency (HTGR-GT binary cycle plant). At $850^{\circ} \mathrm{C}$ turbine inlet temperature, the dry-cooled plant will lave approximately $40 \%$ efficiency and the binary cycle plant, approximately $47 \%$ efficiency. A higher temperature of $950^{\circ} \mathrm{C}$ will increase efficiency to about $43 \%$ and $50 \%$ for the dry-cooled and binary cycle plant, respectively (Ref. 1, 2). Because power conversion is in the primary system, the direct cycle concept eliminates the complex secondary systems associated with a steam cycle plant. This leads to a potential for lower capital costs; and when combined with high efficiency which reduces fuel requirements, this results in a potential for lower overall power generation costs. Potential capital saving relative to a dry-cooled LWR could range from $12-27 \%$ (Ref. 3). Saving is maximized if near $100 \%$ dry cooling is required and if the plant is required to maintain high thermal efficiency at high ambient temperature conditions. 
This paper evaluates the potential benefit to the nation resulting from the introduction of the HTGR-GT.

This report addresses the issue in two ways. First, the role of the HTGR-GT Binary cycle plant is examined in a national energy strategy based on symbiosis between fast breeder and advanced converter reactors utilizing the thorium-U-233 fuel cycle. The economic benefits possible through the introduction of the HTGR-GT are determined as a function of the market share of the HTGR-GT among ACRs operating in the system. Second, the advantages of the HTGR-GT dry-cooled plant operating in arid regions is examined and compared with a dry-cooled LWR. An event tree analysis of potential benefits is applied considering that these benefits are subject to a wide range of uncertainties. 


\subsection{BASE STRATEGY: FBR/ACR SYMBIOSIS}

This section shows the important features of this strategy and the basic assumptions. The strategy is based on an installed nuclear capacity of $400 \mathrm{GWe}$ in the year 2000, and increases at $15 \mathrm{GWe} / \mathrm{yr}$ thereafter. A constant installed capacity of $1000 \mathrm{GWe}$ is assumed after the year 2040. This growth curve is consistent with a 1978 DOE high growth projection which, however, is very much lower than DOE projections made in the past. The period evaluated is from 1975 to 2080 . The evaluation is extended far into the future in order to allow the system to reach a self-sustaining or equilibrium state.

The system is started up on LWRs, with 305 GWe installed by year 2000. ACRs operating on medium enriched uranium are introduced in 1990 at a rate which doubles every two years. The breeders are gradually introduced starting. in year 2000.* In order to reduce the amount of $\mathrm{Pu}$ in stockpile (from LWR discharge) while keeping the number of breeders small initially, Pu-consuming breeders are introduced. These breeders (called Pu-Eaters) are temporarily operated with $\mathrm{U} / \mathrm{Pu}$ cores and thorium blankets. These breeders provide a supply of U-233 necessary for rapid buildup of the U-233 stockpile.

*The latest DOE projection for commercialization of the first breeders assuming an "Early Breeder" strategy, is around 2006 (Ref. 5). The earlier breeder introduction schedule assumed in this report should not drastically affect the overall results as breeders are introduced gradually in the early years. 
In 2005, ACRs fueled with high enriched U-233 are introduced. Later on as the Pu stockpile gets smaller (when LWRs retire) the Puconsuming breeders are converted to $\mathrm{Pu}$ self-sufficient breeders. They are designed to have U/Th blankets. They breed considerably less U-233 than Pu-Eaters. However, the amount of U-233 each Pu self-sufficient breeder produces is enough to feed 3 ACRs fueled with high enriched U-233. This strategy is illustrated in Figure 1 and will serve as the reference case for the evaluation of the effects of the HTGR-GT in a national energy strategy. The choice of the symbiotic system as the reference scenario in this evaluation was highly influenced by the results of previous systems studies which indicated that this system not only has the most favorable power cost but also minimizes proliferation risks and preserves alternatives to meet long term energy needs. (Ref. 4). 


\section{LONG TERM REACTOR STRATEGY}

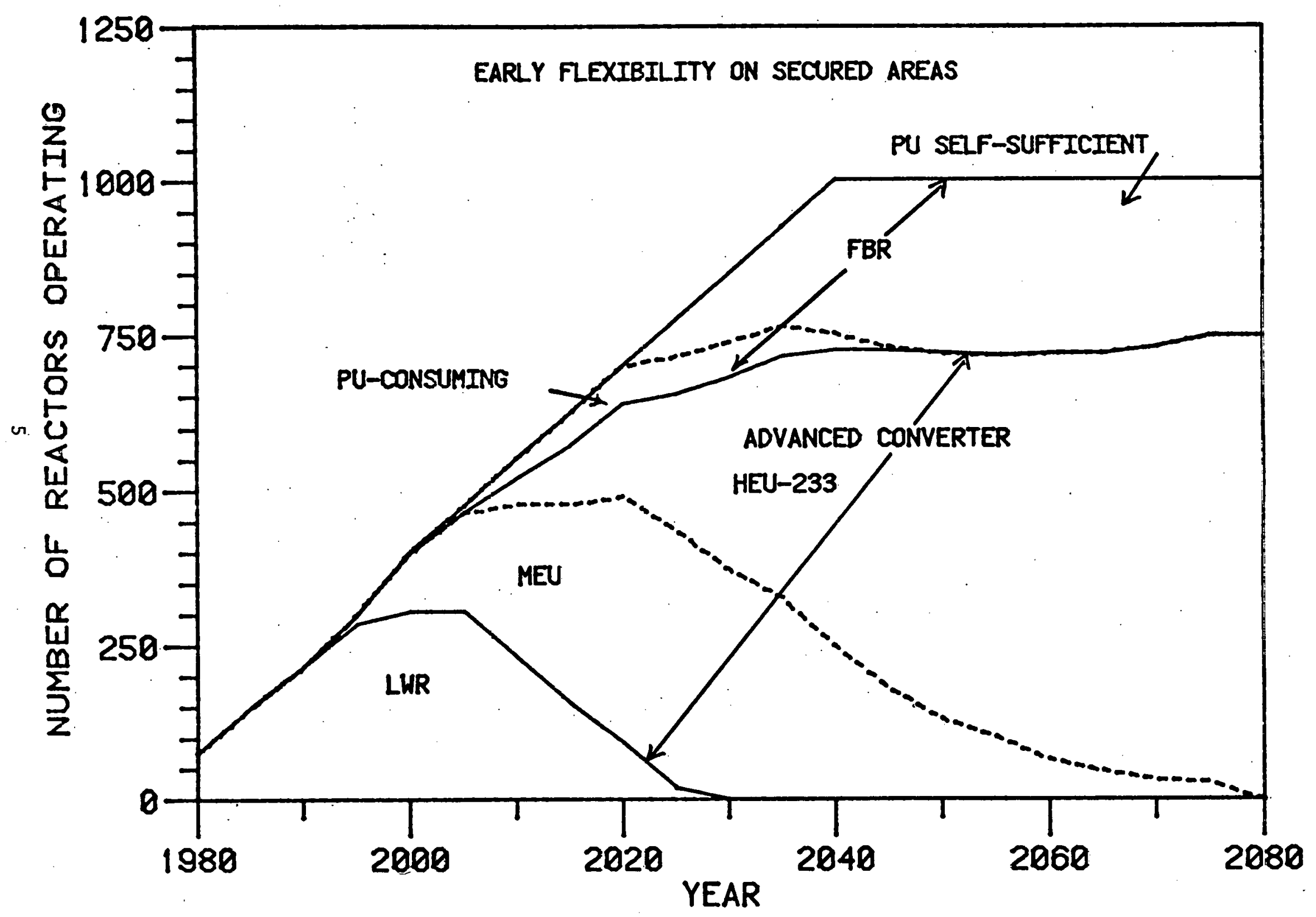

FIGURE 1 


\subsection{EFFECTS OF THE HTGR-GT ON THE BASE STRATEGY}

The potential economic benefits offered by the HTGR-GT in relation to other nuclear reactor concepts are clearly important in justifying future programs.

In this section, we shall examine the possible role of the HTGR-GT in a national energy scenario. To simplify our model, the Binary cycle plant design will be used to represent the HTGR-GT. This particular design combines the gas turbine with a bottoming cycle, resulting in an efficiency of $46.9 \%$ as compared to an HTGR-SC with $39.6 \%$ efficiency and an LWR with $30.7 \%$ efficiency. The dry-cooled HTGR design will be evaluated separately in Section 4, in a scenario where it could be particularly useful, namely in arid or water-poor regions.

The benefits derived from deploying the HTGR-GT (Binary cycle plant) in an energy scenario discussed in Section 2 are evaluated in terms of the extent of its market penetration in competition with other ACR types. In this study, the HTGR-GT is assumed to be commercially available by year 2003. By the year 2010, the market share of the HTGR-GT among other ACRs installed (from the Base Case) is assumed to be 0,10 , 30,50 and $100 \%$. (The $100 \%$ penetration is meaningful only for comparative purposes.)

The market share of the HTGR-GT and the assumed range in capital cost relative to a standard LWR of $.89-1.03$ are used as parameters to calculate the total discounted cost of the system. Appendix A lists the fuel cycle characteristics and cost assumptions used in the analysis. 
Since plant design studies are still underway to establish the optimum design configuration for the HTGR-GT commercial plant, these assumptions are subject to change as more data become available.

The results of the cost calculations performed are best illustrated in Figure 2. This represents one possible range of benefit with the deployment of the HTGR-GT in a symbiotic energy system over the period 1980 to 2080. (Costs were discounted to $2000 \$$ at $4.5 \%$.) *

Fig. 2 shows that if $50 \%$ of all ACRs installed were HTGR-GTs, the cost saving to the nation could range from $\$ 30-55$ Billion (in discounted $2000 \$$ ). This potential benefit is meaningful enough to warrant support for the development of the direct cycle concept. Other intangible benefits such as siting flexibility, minimum environmental impact and applications of reject heat (i.e., water desalination, district heating/air conditioning, low temperature process heat, agriculture) are further incentives for the HTGR-GT.

* LWRs are likely to dominate the nuclear power scenario until the year 2000 , with advanced concepts being deployed starting in the year 2000 or even later. Therefore, costs were discounted to the year 2000 (setting aside all costs incurred before the year 2000) in order to provide results that are indicative of the future economic situation. 
POTENTIAL BENEFIT OF THE HTGR-GT IN A SYMBIOTIC SYSTEM

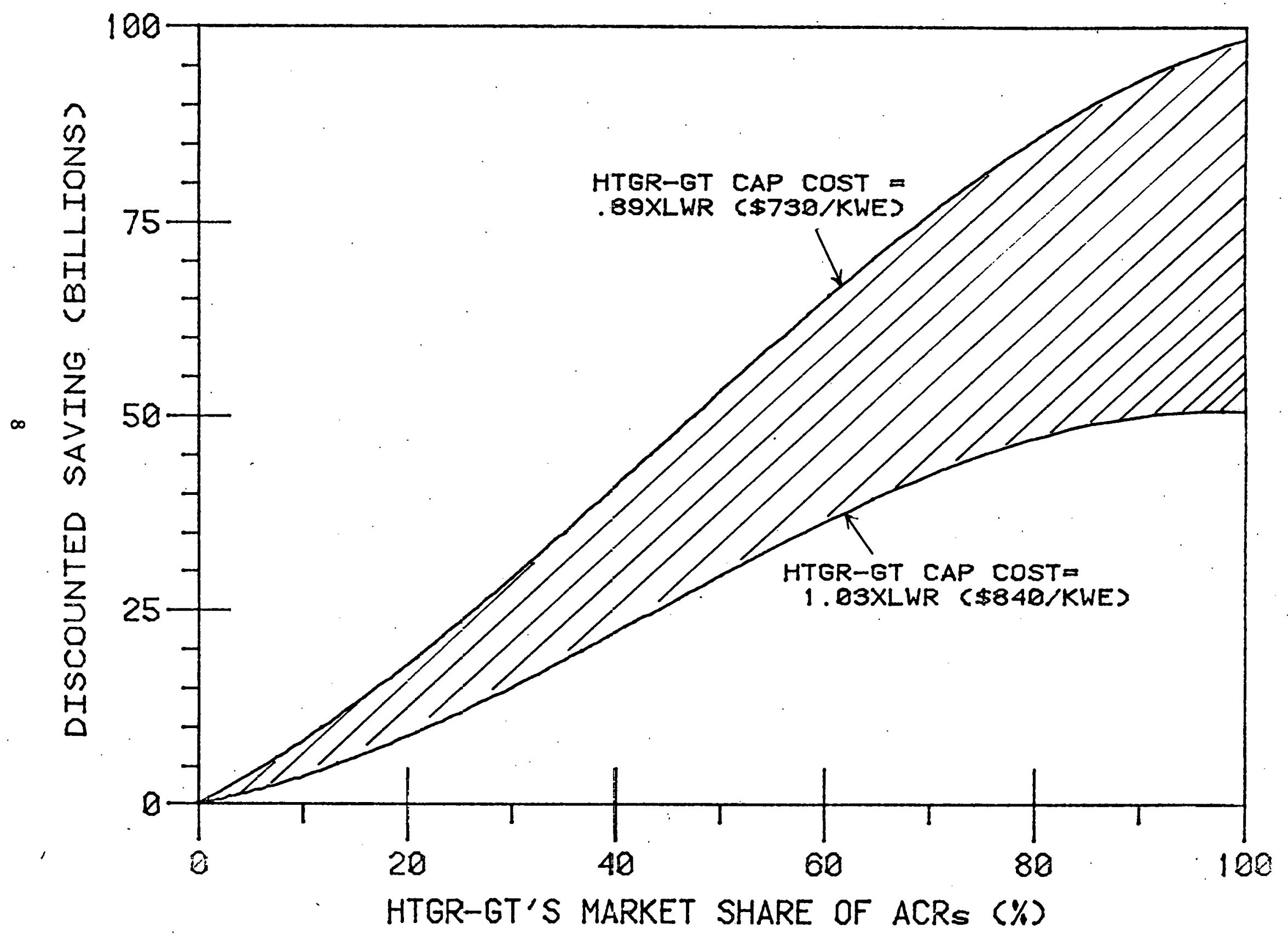

FIGURE 2 


\subsection{STRATEGY FOR ARID REGIONS}

The relatively high temperature heat rejection of the HTGR-GT makes it well suited for dry cooling and a highly attractive option for water-poor regions. In this section, this potential is evaluated in a strategy for arid regions where the choice for future power plants would be limited to either a dry-cooled LWR or a dry-cooled HTGR-GT.

Two HTGR market shares are assumed for this strategy. The high market share represents $30 \%$ while the low market share represents $10 \%$ of U.S. nuclear requirements (Sec. 2). Of course, the introduction schedule constraints* on the HTGR-GT would limit the number of reactors operating during the first few years. The total cost (capital, handing, fuel) for all HTGR-GT reactors installed over the period 2000-2040 is calculated for each market share. Similar calculations are performed using the LWR-dry-cooled fuel and cost characteristics; i.e., the same number of LWRs are installed as the HTGRs (dry-cooled).

Tahle 1 lists the assumptions used in the analysis. Figure 3 illustrates schematically the total discounted (at $4.5 \%$ ) costs for the two systems as a function of the capital cost relative to the wet-cooled LWR. For the high demand, the cost benefit of the HTGR-GT ranges from $\$ 45$ to 65 Billion or 26 to $40 \%$ (in 2000 \$) compared to the dry-cooled LWR. The higher efficiency (10\% more) of the HTGR-GT, by itself, accounts for at. lexst $\$ 30$ Billion or $15 \%$ saving. The efficiency effect was calculated by assuming that the capital cost for the HTGR would be the same as the dry-cooled LWR.

*HTGR-GT deployed by year 2003 at a rate which doubles every two years. 
TABLE 1

ASSUMPTIONS

DRY-COOLED

HTGR-GT LWR

Efficiency $(\%)$

39.6

30.7

Fuel Cycle

MEU-U Recycle

LEU-U Recycle

Capital ( $\$ / \mathrm{KWe})$

$730-840$

$950-1005$

Capital Cost Ratio**

$.89-1.03$

$1.16-1.23$

*1979\$

**Relative to Wet-conled LWR

Source: GCRA, "High Temperature Gas-Cooled Reactor Assessment", March 1979. 
TOTAL COST CUTLAY AS A FUNCTION OF CAPITAL COST

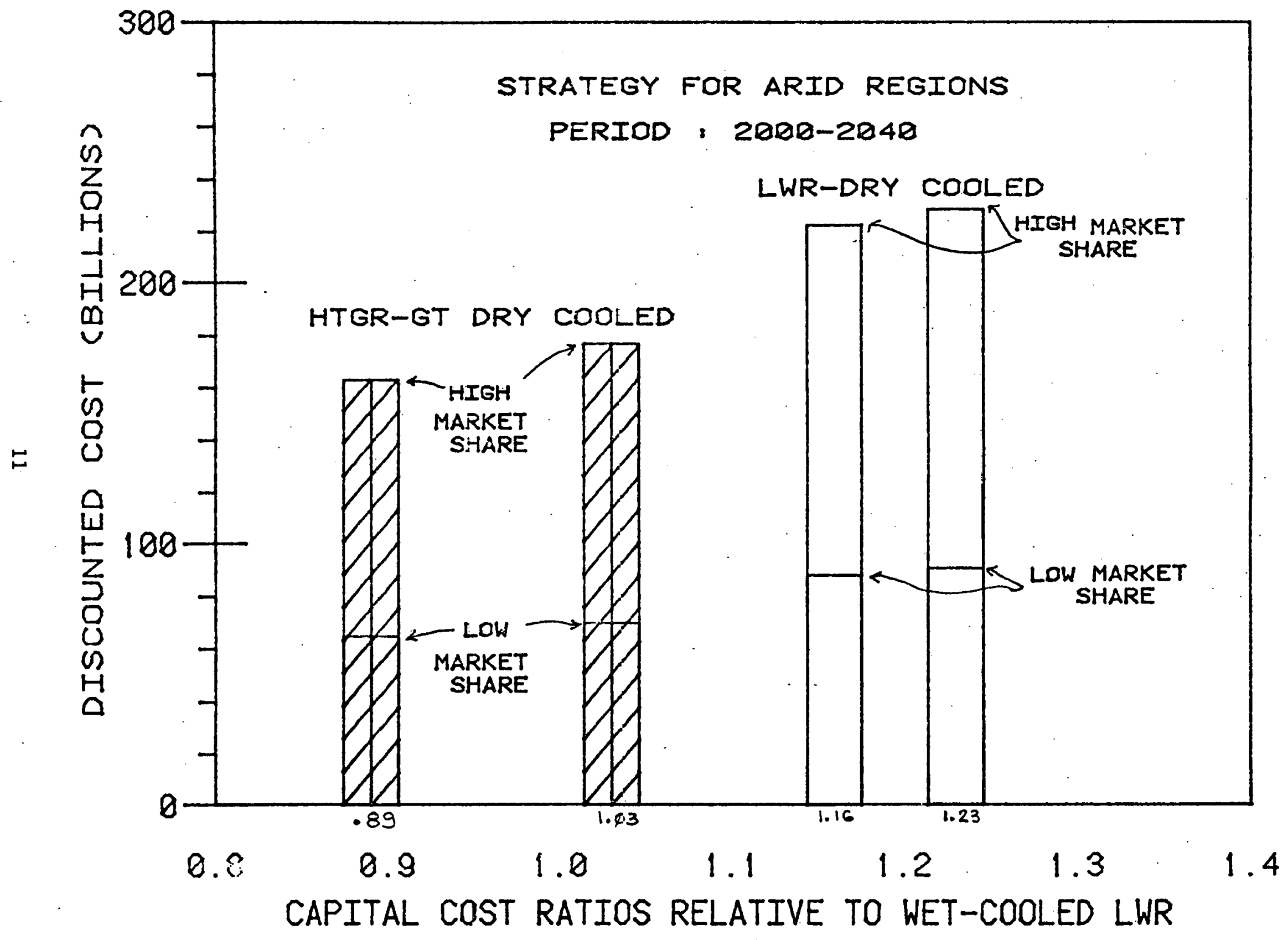

FIGURE 3 
Calculating the power cost of a system for a fixed time frame may present some short comings in the sense that the cost of reactors built in the later years are not truly reflected in the total cost. A more common approach is to calculate the equilibrium or levelized power costs in mills/kwh. Table 2 compares the power costs of the HTGR-GT with the wet-cooled and dry-cooled LWRs, assuming different fuel cycle scenarios. The use of high enriched fuel and higher fuel efficiency achieved by increasing the gas turbine inlet temperature to $850^{\circ} \mathrm{C}$ and adopting a. 3-year refueling cycle could further reduce power cost by $7 \%$. Maximum HTGR advantage (low range capital cost, with optimized fuel recycle) over the wet-cooled LWR and dry-cooled LWR is 17.4 and $41.5 \mathrm{mills} / \mathrm{kwh}$, respectively. These cost component data were derived from Ref. 3 . Fuel costs were levelized for 15 years.

\subsection{EVENT TREE ANALYSIS}

Because of the uncertainties in power cost estimates, an event tree sequence for assessing the potential benefits of the HTGR-GT is dcsirable. Several events influence the benefits which were shown in Figure 3. The probability that these events will occur must be estimated. A decision tree as illustrated in Figure 4 is used for this purpose. The probabilities assigned to each event in the tree represent judgements by the authors, based upon a limited survey.

By calculating the product of all probabilities along the branches that form a scenario, one obtains the overall probability for that scenario. The probability that a benefit will be equal to or greater than any specific number is obtuined by plotting the data in Figure 4 and approximating the interval between data points by using the least squares method and assuming a third degree polynomial fit. The cumulative probability distribution is illustrated in Figure 5 . 
TABLE 2

POWER COST COMPONENTS

(mills/kwh, 2000\$)

LWR-Wet Cooled LWR-Dry-Cooled HTGR-GT, Dry Cooled

Efficiency

Capital

Fuel $\left(\$ 100 / 1 \mathrm{~b} \mathrm{U}_{3} \mathrm{O}_{8}\right)$

No Recycle $e^{(a)}$

Full Recycle $e^{(b)}$
$(33.4 \%)$

78.4

$-$

50.2

43.3
$(30.7 \%)$

$92.5-98.2$

54.8

47.2
$(39.6 \%)$

$70.6-81.7$

46.8

35.8

$33.3^{(c)}$

(a) LWR-LEU fuel; HTGR-MEU/Th fuel

(b) LWR-U/Pu recycle; HTGR-HEU

(c) $\mathrm{HEU}$ full recycle, $43 \%$ efficiency

Source: GCRA High Temperature Gas Cooled Reactor Assessment, March 1979. 


\section{FIGURE 4}

SAMPLE ASSUMPTIONS FOR EVALUATING BENEFITS OF THE HTGR-GT*

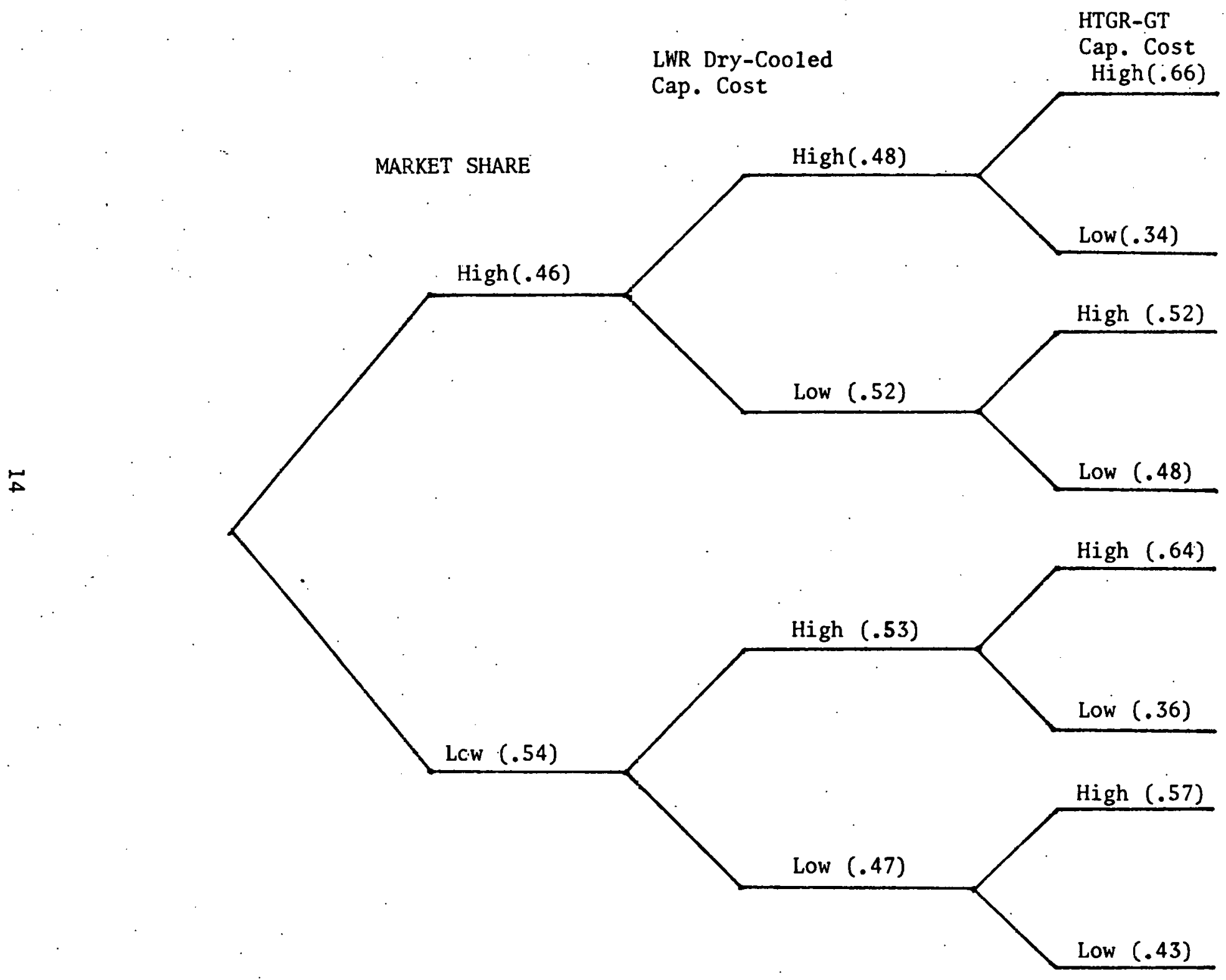

Benefit (\$B)

51.7 (.15)

$65.4(.09)$

$44.8(.12)$

$58.5(.11)$

$20.7(.18)$

$26.0(.10)$

$18.0(.14)$

${ }^{*}$ Nos. in parenthesis $=$ probabilities 
PROBABILITY DISTRIBUTION

BENEFIT FROM HTGR-GT CDRY-CODLED) REL. TO LWR

È

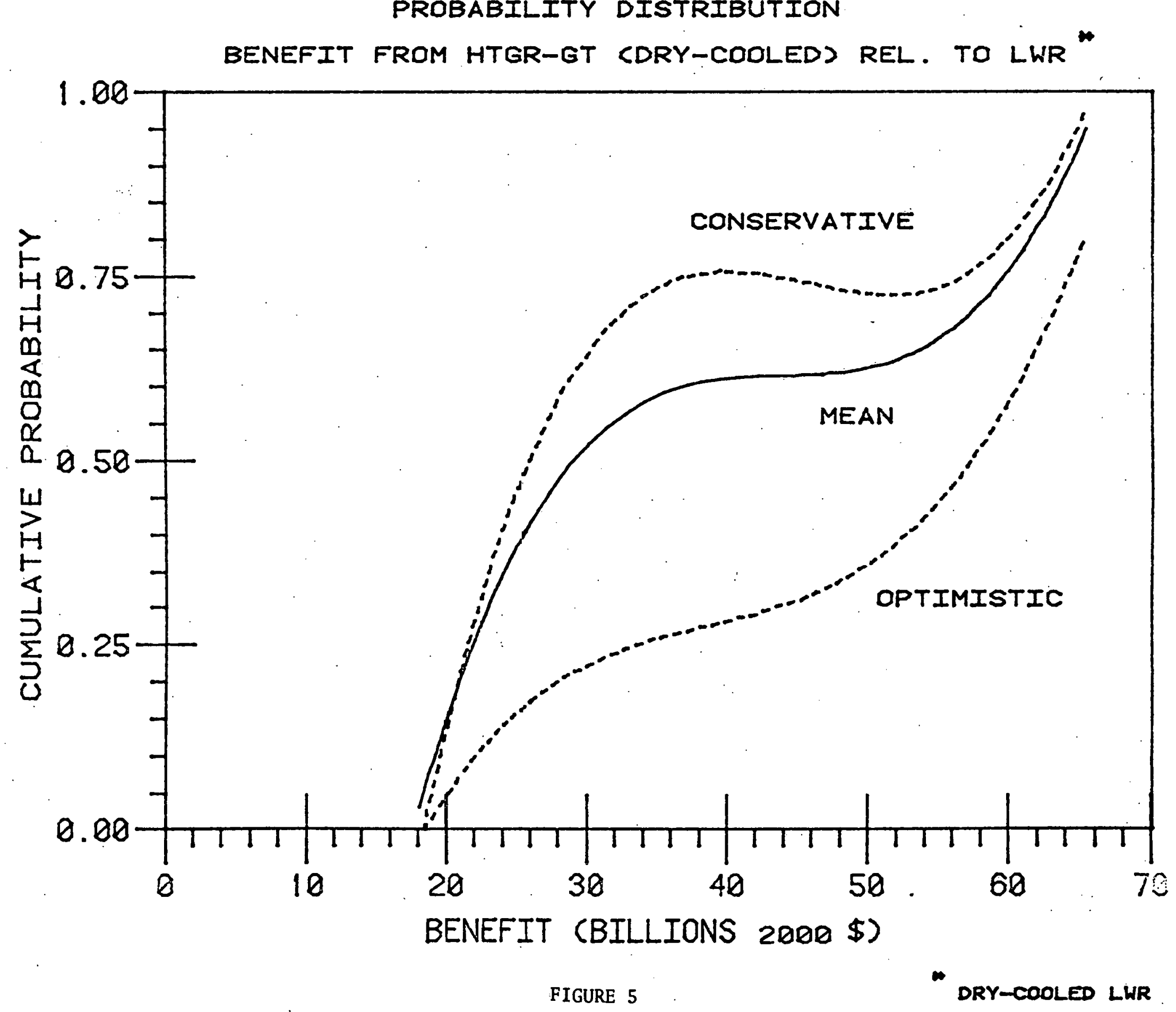


Assuming a very conservative climate for the HTGR-GT, there is a $50 \%$ probability that the benefit to the nation relative to the dry-cooled LWR would be no greater than $\$ 26$ Billion. On the other hand, if future events prove highly favorable for the HTGR, the benefits could be no greater than $\$ 56$ Billion (at $50 \%$ probability).

Two factors, namely, capital and fuel cycle costs, greatly influence the reduction in the HTGR's power cost relative to the drycooled LWR. Again, there is a range of uncertainty on how much the overall capital cost could be reduced and what fuel cycle scenario would eventually be used. Capital and fuel cycle cost factors relative to the dry-cooled LWR were calculated from the data given in Table 2 . In Figure 6, each cost factor is assigned probabilities in the same manner done earlier (Fig. 4). A range in fuel cycle cost factor is given for each fuel cycle scenario to indicate some degree of uncertainty in predicting such costs at present. The overall power cost factor is the product of the capital and fuel cost factors.

Figure 7 displays schematically the uncertainty on the overall power cost factor. From an optimistic standpoint, there is a $75 \%$ probability that the power cost of the dry-cooled HTGR will be less than or equal to $85 \%$ that of the dry-cooled LWR. A more conservative view indicates that there is a $20 \%$ probability that the power cost will be less than or equal to $95 \%$ of the LWR.

The probabilistic analysis performed in this study has only touched the tip of the iceberg. A more rigorous treatment of uncertain-. ties and components affecting the costs is necessary for a more exhaustive analysis. 
FIGURE 6

DECISION TREE FOR FACTORS AFFECTING HTGR-GT POWER COST RELATIVE TO DRY-COOLED LWR*

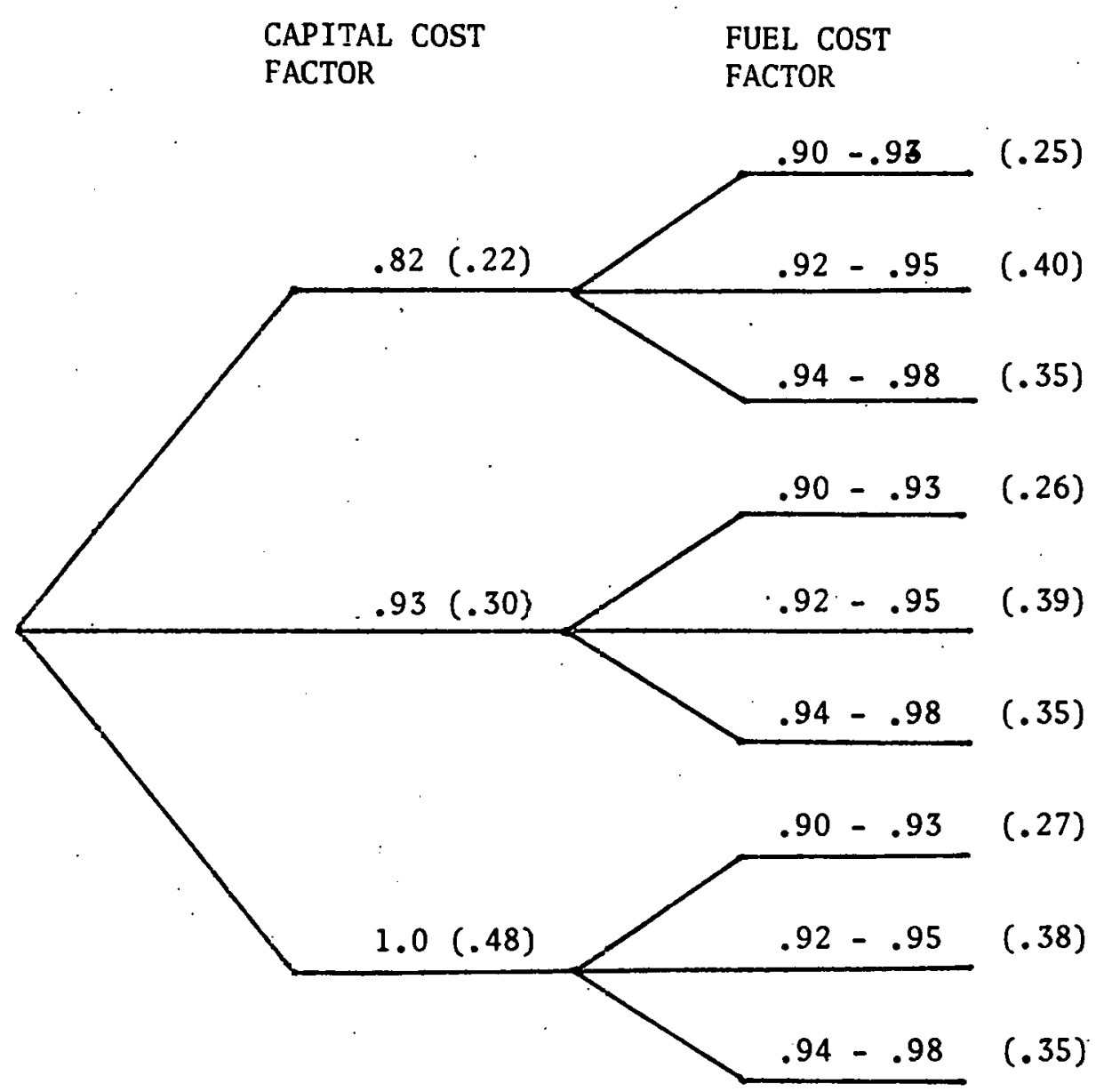

OVERALL POWER

COST FACTOR

$$
\begin{aligned}
& .76(.06) \\
& .78(.088) \\
& .80(.077) \\
& .85(.078) \\
& .87(.117) \\
& .89(.105) \\
& .92(.130) \\
& .94(.182) \\
& .96(.168)
\end{aligned}
$$

${ }^{*}$ Nos in parentheses $=$ probabilities 
COST UNCERTAINTY OF A DRY-COOLED HTGR

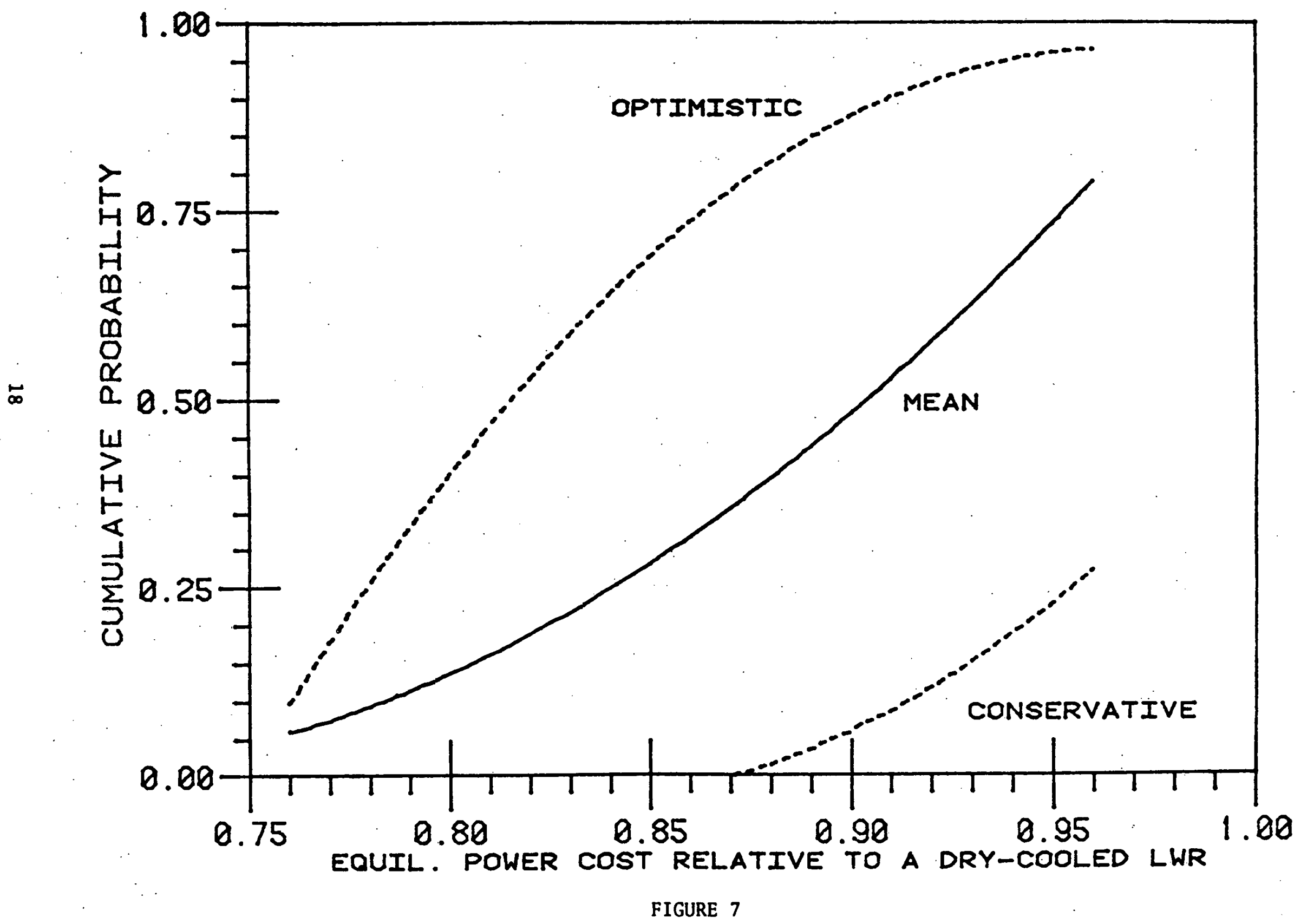




\subsection{CONCLUSION}

This economic analysis of the HTGR-GT shows the potential for substantial benefits within the restricted analysis presented herein. The results also indicate that the gas turbine system need not be limited to arid regions. It could play an active role in symbiotic systems to meet the nation's energy needs. However, the achievement of these benefits depends on such factors as the date of commercial introduction, the government decision on fuel reprocessing, etc.

More work is required to carry out a rigorous probabilistic treatment of uncertainties in estimating the power cost. Such information is particularly useful in the assessment of alternative reactor systems.

The direct cycle concept shows advantages not only in economics but also in other unquantified benefits it offers, i.e., siting, flexibility, process heat applications, etc. 


\subsection{REFERENCES}

1. McDonald, C. F., "The Nuclear Closed-Cycle Gas Turbine - A Utility Power Plant of the Future", GA Report GA-A15082, August 1978.

2. McDonald, C. F. and K. Vepa, "Ammonia Turbomachinery Design Considerations to the Direct Cycle Nuclear Gas Turbine Waste Heat Power Plant", GA-A14171, January 1977.

3. High Temperature Gas Cooled Assessment, Gas Cooled Reactor Associates Report, March 1979.

4. Turner, R. F., et.al., "Analysis of Nuclear Systems Satisfying U.S. Energy Needs", GA Report \#GA-A14848, February 1978.

5. Internal Memo, R. A. Moorc to J. H. Broido, Octuber 23, 1979. 
INVENTORY REQUIREMENTS

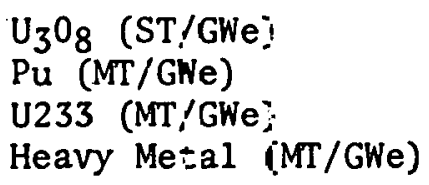

NET OPERATING REQUIREMENTS

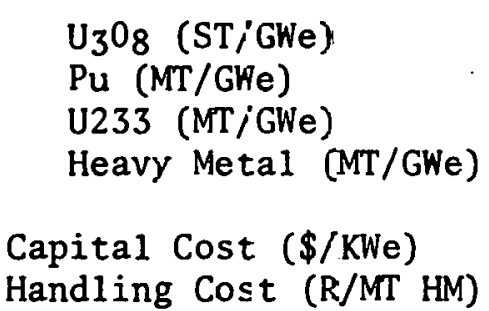

*At $70 \%$ Capacity factor and $.1 .5 \%$.tails.

Notes: 1. Inventory and Net operating requirements for the LWR-dry cooled $=$ LWR-Wet cooled $\times \frac{33.4}{30.7}$

2. Inventory and Net operating requirements for the HTGR-GT $=$ HTGR-SC $\times \frac{39.6}{46.9}$

3. (Binary cycle) HTGR-GT Capital cost $=730-840(\$ / \mathrm{KWe})$

4. HTGR-GT Handling C.Jst $=$ HTGR-SC $\times 1.10$.

$$
\begin{gathered}
4.8 \\
100
\end{gathered}
$$

GCFR-U/Pu Core GCFR-U/Pu Core

\section{LWR-U Recyc-e HTGR-MEU-SC HTGR-HEU233-SC U/Th Blankets Th/Th Blankets}

$\begin{array}{ccc}460 & 385 & - \\ - & - & - \\ - & - & 2.30 \\ 78.2 & 30.6 & 78.6\end{array}$

$$
-
$$$$
129.3
$$

$\begin{array}{cc}133 & 85 \\ -.15 & -.027 \\ - & - \\ 25.1 & 6.8 \\ 817 & 840 \\ 4.85 \times 10^{5} & 1.26 \times 10^{6}\end{array}$

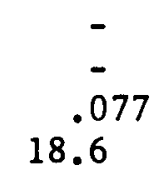

$$
\begin{gathered}
- \\
- \\
-.26 \\
21.1 \\
1010 \\
1.16 \times 10^{6}
\end{gathered}
$$$$
\begin{array}{r}
.16 \\
-.40
\end{array}
$$$$
29.5
$$$$
1010
$$$$
1.15 \times 10^{6}
$$ 


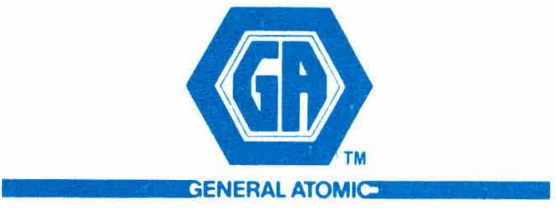

GENERAL ATOMIC COMPANY

P. O. BOX 81608

SAN DIEGO, CALIFORNIA 92138 